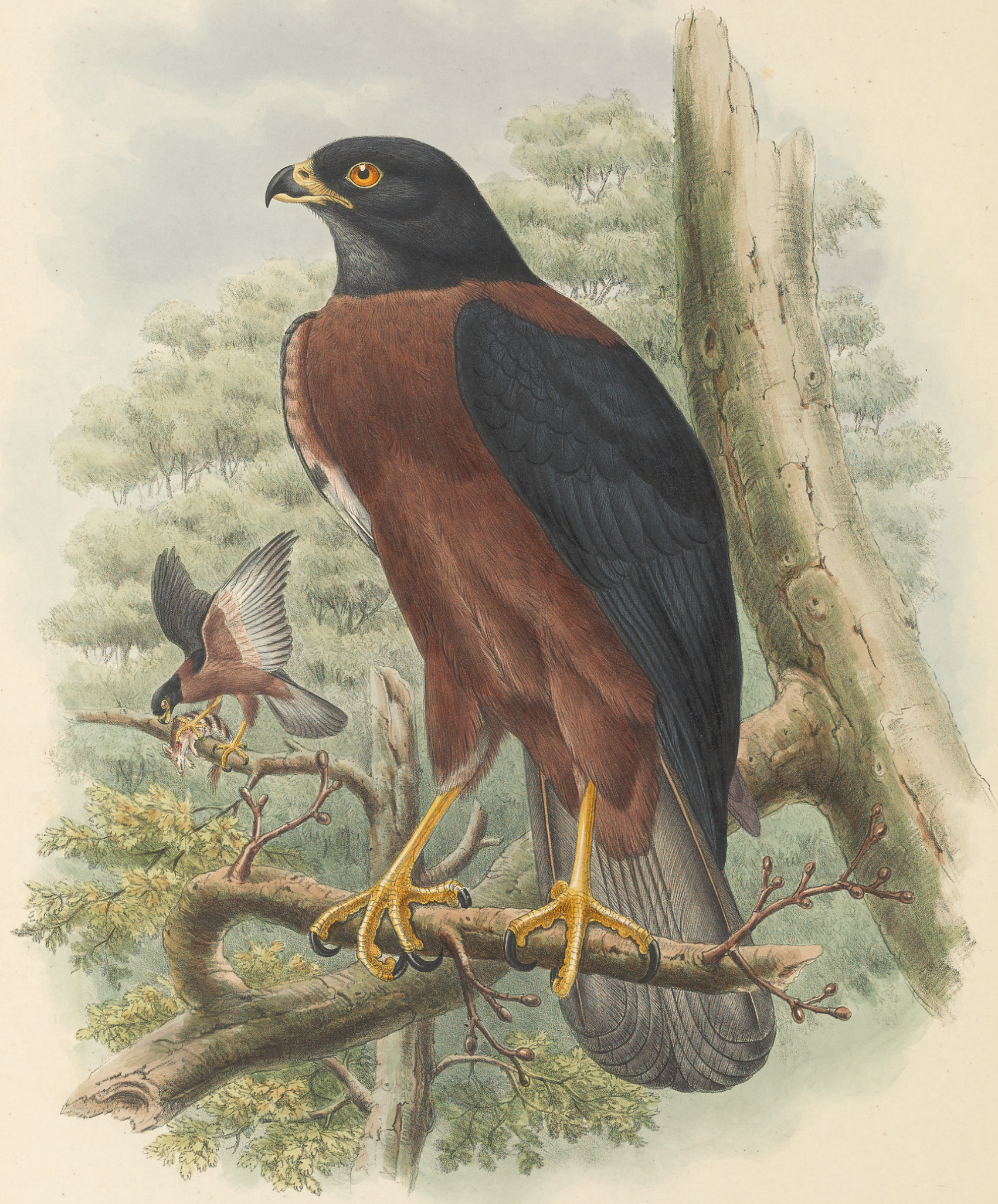




\section{ASTUR MELANOCHLAMYS.}

\section{Black-mantled Goshawk.}

Urospizias melanochlamys, Salvad. Ann. Mus. Civic. Genov. vii. p. 905 (1875).-Id. op. cit. xii. p. 38 (1878).-Id. Orn. Papuasia e delle Molucche, i. p. 63 (1880).

Astur melanochlamys, Sharpe, Mitth. k. zool. Mus. Dresd. Heft iii. p. 355 (1878).

THIs fine species is at present only known from the Arfak Mountains in North-western New Guinea, whence the first specimens were sent to Europe by Mr. Bruijn and Dr. Beccari. We have also seen a specimen in Dr. Guillemard's collection from the same locality.

This Goshawk is a very distinct species, and belongs to the Austro-Malayan section of the genus Astur, which embraces the species which have a rufous collar round the hind neck. It differs from all its allies, however, by having the ear-coverts slaty black like the head and back, and by the deep vinous chestnut of the under surface.

The following description was taken by us from the type specimen belonging to the Genoa Museum, a sight of which was granted to us by Count Salvadori during his last visit to England :-

Adult female. General colour above deep black; head black like the back, from which it is separated by a broad well-defined collar of vinous chestıut; quills and tail black like the upper surface, the inner webs rather browner, barred with black; entire sides of face black like the crown; throat also black, but mottled with white bases to the feathers, many of the latter being white barred with black; remainder of under surface of body deep vinous chestnut, with slightly developed whitish bars on the flanks and lower abdomen ; under wing-coverts and axillaries vinous chestuut, with remains of lighter cross bars, the greater series and the inner webs of the quills greyish white with a vinous tinge and barred with blackish. Total length $15 \cdot 2$ inches, culmen $1 \cdot 1$, wing $10 \cdot 0$, tail $7 \cdot 8$, tarsus $2 \cdot 65$.

The Plate represents an adult bird of about the size of life, with a smaller figure in the background. Both are drawn from a specimen procured by Dr. Guillemard in the Arfak Mountains, and kindly lent to us by that gentleman. 


\section{$2 \mathrm{BHL}$ Biodiversity Heritage Library}

Gould, John and Sharpe, Richard Bowdler. 1886. "Astur melanochlamys, Black-mantled Goshawk [PI. 1]." The birds of New Guinea and the adjacent Papuan islands : including many new species recently discovered in Australia 1(XXII), -. https://doi.org/10.5962/p.322602.

View This Item Online: https://www.biodiversitylibrary.org/item/229855

DOI: https://doi.org/10.5962/p.322602

Permalink: https://www.biodiversitylibrary.org/partpdf/322602

\section{Holding Institution}

Smithsonian Libraries

\section{Sponsored by}

Biodiversity Heritage Library

\section{Copyright \& Reuse}

Copyright Status: Public domain. The BHL considers that this work is no longer under copyright protection.

This document was created from content at the Biodiversity Heritage Library, the world's largest open access digital library for biodiversity literature and archives. Visit BHL at https://www.biodiversitylibrary.org. 